\title{
The Enduring Lure of Socialism: the Political Economy of the Subprime Crisis
}

\author{
by Dóra Györffy
}

\begin{abstract}
Market failure and the need for stronger state involvement in the economy has become the dominant perspective in the interpretation of the subprime crisis. After providing a brief description of the evolution of the crisis, the paper challenges this view by showing how monetary, fiscal and regulatory policy in the United States contributed to the crisis through giving rise to false perceptions of risks and encouraging excessive indebtedness for both financial sector actors and households. These policies are not due to random mistakes, but rather reflect illusions about technological progress and the possibilities of risk management. Whether these beliefs were genuine or served to conceal identifiable political purposes, they should make us equally careful about advocating greater state involvement in the economy. Parallels with socialist and post-socialist experiences are used to illuminate these arguments. ${ }^{1}$
\end{abstract}

Bei der Interpretation der gegenwärtigen Finanzkrise geht die dominante Sichtweise von Marktversagen und der Notwendigkeit verstärkten staatlichen Engagements in der Wirtschaft aus. Nach einer kurzen Beschreibung der Entwicklung der Krise stellt der vorliegende Beitrag diese Sichtweise in Frage, indem er zeigt, wie die Geld-, Fiskal- und Regulierungspolitik der Vereinigten Staaten zur Krise beigetragen hat, indem sie falsche Risikoeinschätzungen genährt und Anreize zu übermäßiger Verschuldung sowohl des Finanzsektors als auch der privaten Haushalte geboten hat. Diese Effekte sind nicht auf zufällige Fehler zurückzuführen, sondern spiegeln Illusionen über den technischen Fortschritt und die Möglichkeiten des Risikomanagements wider. Unabhängig davon, ob diese Annahmen tatsächlich vorhanden waren oder nur vorgebracht wurden, um erkennbare politische Ziele durchzusetzen, sollten sie Anlass zur Vorsicht vor dem Ruf nach einer stärkeren Rolle des Staates in der Wirtschaftsordnung geben. Parallelen zu sozialistischen und post-sozialistischen Erfahrungen verdeutlichen diese Argumente.

\section{Introduction}

After being out of favour for decades, the subprime crisis brought the views of Karl Marx and John Maynard Keynes back into fashion all around the world.

1 With the usual caveats I am grateful for helpful comments on an earlier version of this paper to László Csaba and Júlia Király. The research was supported by the Bolyai Fellowship of the Hungarian Academy of Sciences. 
Former US President George Bush stated on CNN television (17 December 2008) that he had given up his belief in free markets. His successor, Barack Obama seems to be thinking along the same lines and cited openly Keynesian principles in his justification for the $\$ 800$ bn bailout package that was accepted within a few days after he assumed power. In the meantime the Federal Reserve (FED), after reducing the interest rate to practically $0 \%$ is thinking about alternative ways to increase the money supply in the economy. With few exceptions these policies are copied around the world as governments attempt to counter the effects of the global crisis through bailout packages and low interest rates. Even the International Monetary Fund (IMF), which has been so often criticised for its dogmatic stance on fiscal matters, is expecting Keynesian policies from governments $^{2}$. From these measures it appears that the state has to correct the failure of markets and the lessons for the future seem obvious - in order to avoid a similar crisis in the future, increasing state involvement in the economy is unavoidable.

In the midst of growing enthusiasm for stricter regulations, the role of the state in the crisis seems to be somewhat neglected. This contribution focuses on how governmental policies, most importantly the easy monetary policies of the FED and the politically motivated relaxation of credit standards, distorted the incentives of market participants and led to the accumulation of excessive risks in the financially system. Based on the policy discourse it is also shown that failure to counteract these risks through market regulation was due to false beliefs in the capability of financial innovation techniques to manage these risks. When taking a closer look at these methods, however, one can argue that their popularity with regulators was probably as much due to political economy factors as to their scientific foundations.

The contribution proceeds as follows. The next section will provide a brief overview about the evolution of the subprime crisis on the basis of Charles Kindleberger's crisis model, which focuses on asset price bubbles. The third part tries to answer the question in what ways the various actors (FED, US government, financial market actors and households) contributed to the development of the crisis. The fourth section discusses the political economy aspects of the crisis and tries to decipher why no action was taken to fight the emerging bubble through drawing some parallels with socialist and post-socialist experiences.

2 http://www.imf.org/external/pubs/ft/survey/so/2008/INT122908A.htm. 


\section{The Anatomy of the Crisis}

While at the beginning of the crisis a number of observers interpreted the events as unprecedented, with the time passing it has become clear that we are not facing a completely new phenomenon. In the following I interpret the crisis on the basis of the model developed by Charles Kindleberger. This model analyses financial crises in four distinct stages. ${ }^{3}$

Stage 1. A monetary expansion leads to increased credit supply, and creates the conditions for speculative transactions in certain segments of the economy. During this process the price of assets are less and less determined by fundamental factors, but rather by expectations about their future price. Claudio Borio explains this occurrence by the presence of a positive feedback mechanism between liquidity, asset prices and output. ${ }^{4}$ Robert Shiller points to several mechanisms through which the bounded rationality of investors can give rise to selffulfilling expectations regarding asset prices. ${ }^{5}$ In the past centuries almost any asset could become an object of speculation including corporate or government bonds, raw materials, land, real estate, railways or even tulip bulbs.

Stage 2. As a consequence of speculative investments, asset bubbles emerge and the vulnerability of the economy to crisis increases. This stage is characterised by growing indebtedness, underpricing of risks as well as scams and swindles. The latter gain further momentum as actors try to counteract their losses. A further element of this stage is the attempts to rationalise the bubble and justify the prices on the basis of long-term trends.

Stage 3. At a certain point an unfavourable shock, such as monetary restriction, occurs and investors' expectations change. After some investors sell their assets, a general fright prevails and the stampede leads to a self-reinforcing fall of prices. During this process the banks' portfolios deteriorate and their liquidity declines. This makes them unable to provide new loans, which in turn reinforces the negative spiral of asset price decline.

Stage 4. The crisis erupts when the fall of one institution threatens with systemic failure, and governmental intervention becomes necessary.

3 Kindleberger, C.P.: Manias, Panics and Crashes, $2^{\text {nd }}$ ed., Basingstoke/London, 1989.

4 Borio, C.: Change and Constancy in the Financial System: Implications for Financial Distress and Policy, BIS Working Paper No. 237, 2007, 9.

5 Shiller, R. J.: Irrational Exuberance, Princeton, NJ, 2000. 
Although Kindleberger built his model primarily on the basis of $18^{\text {th }}$ and $19^{\text {th }}$ century events, it can also help us to provide a coherent interpretation of the subprime crisis. To illustrate this interpretation, Figure 1 gives a summary of the major factors of the crisis showing US interest rate, inflation, growth and housing prices between 1995 and 2008.

Figure 1: Growth, inflation, interest rates and house prices in the US, 1995-2008 (\%)

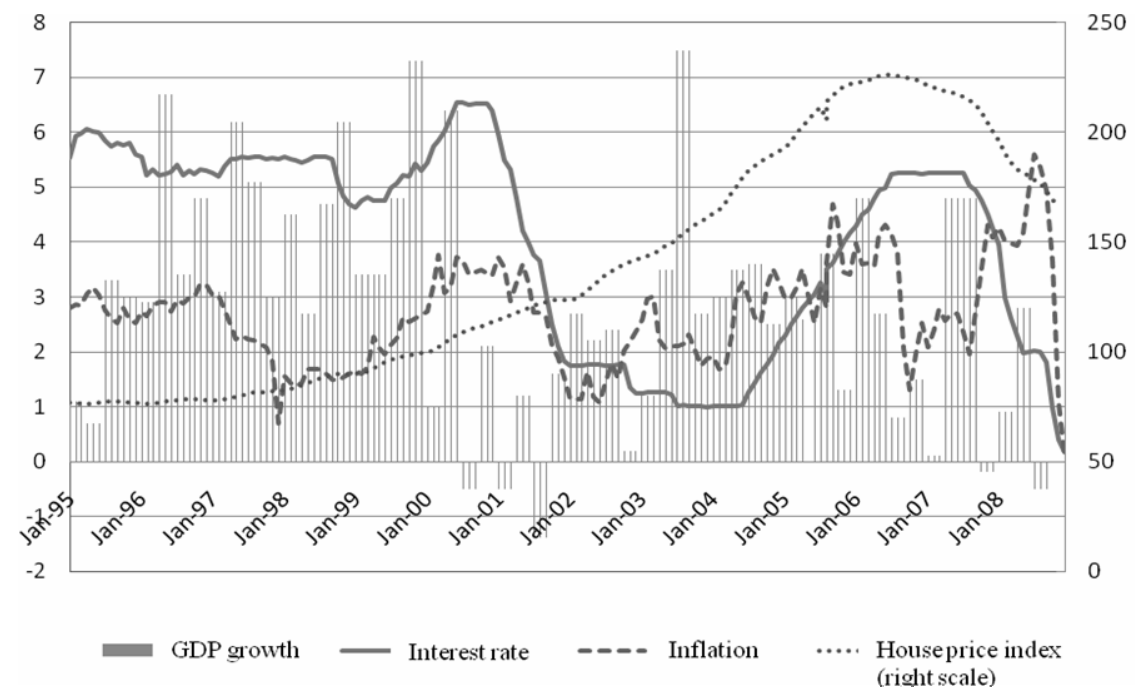

Source: Author's compilation based on: GDP growth: quarterly data, Bureau of Economic Analysis, http://www.bea.gov/national/index.htm\#gdp; Interest rate: monthly data, federal funds overnight rate, http://www.federalreserve.gov/releases/h15/data/Monthly/H15_FF_O.txt; Inflation: CPI monthly data year-to-year change: St. Louis Federal Reserve Bank, http://research.stlouisfed.org/fred2/series/ CPIAUCNS?cid=9; Houseprice index: Case-Shiller 10-city composite index $(2000=100 \%)$ : http://www2.standardandpoors.com/portal/site/sp/en/us/page.topic/indices_csmahp/0,0,0,0,0,0,0,0,0, $1,3,0,0,0,0,0 . \mathrm{html}$.

\section{Monetary Expansion}

As it can be seen from Figure 1, the fast increase in housing prices started already in 1997 but gained momentum only in 2001. Based on the figure three issues deserve to be mentioned to account for this occurrence. 1. The fast growth of the 1990s came to an end, and the economy had negative growth rates in three 
quarters. The slowdown was due to two factors: first, this was the time when the dot.com bubble burst (I will return to it in the next section); second, the events of 9/11 also had negative effect on growth and expectations. 2. The slowdown of the economy was accompanied by low inflation, which declined from around 3 percent to close to 1 percent. 3. These two factors make it less than surprising that the FED engaged in a sharp reduction of interest rates - between November 2000 and January 2002 interest rates were cut from 6.5 to $1.75 \%$.

The real monetary expansion however took place only from mid-2002. Inflation started to rise in the second part of 2002, and in the second quarter of 2003 growth also resumed. At the same time interest rates remained below inflation as long as August 2005, which means negative real interest rates for two and a half years and thus a very strong incentive for increasing indebtedness. As Figure 1 shows, this is the period when the trend of increasing house prices accelerated.

Besides negative real interest rates fiscal policy also contributed to growth in liquidity. As it can be observed in Figure 2, the surplus accumulated in the late 1990s turned into a large deficit after 2001. This was partly due to tax cuts and partly to the costs of wars against Afghanistan and Iraq.

Figure 2: US Government budget balance (\% of GDP)

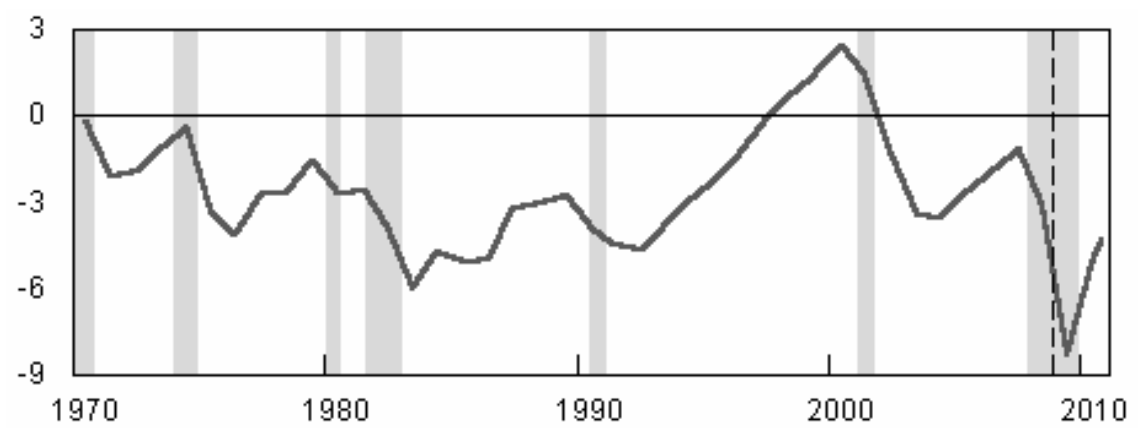

Note: Grey lines indicate recessionary periods.

Source: Congressional Budget Office, http://www.cbo.gov/doc.cfm?index=9957.

Finally, when explaining liquidity growth, global factors also have to be taken into account besides US monetary and fiscal policy. The "global saving glut" as termed by current FED chairman, Ben Bernanke, means that the accumulation of large current account surplus of Asian countries and their enormous dollar reserves helped to finance the current account deficit of the US and thus contrib- 
uted to ample liquidity on financial markets. The availability of financing from the global markets also implied that there was no incentive for US economic actors to limit their consumption and accumulate savings. ${ }^{6}$

The enormous liquidity, which came as a consequence of the above three factors, led to a sharp increase in risk-taking, since normal returns in this environment were possible only through taking high risks and high leverage. The management of risks was helped through the enormous acceleration of financial innovation. The unbundling and re-bundling of payoffs from different financial assets allowed the separation of exchange rate, interest rate and most recently also credit risks $^{7}$. Due to the growth of structured finance products, which is illustrated by Figure 3, it appeared that investors could not only freely choose the risk of their portfolio, but these new derivatives also allowed the reduction of overall risk in the system.

Figure 3: Number of Ratings Outstanding at the Beginning of Each Year in Europe

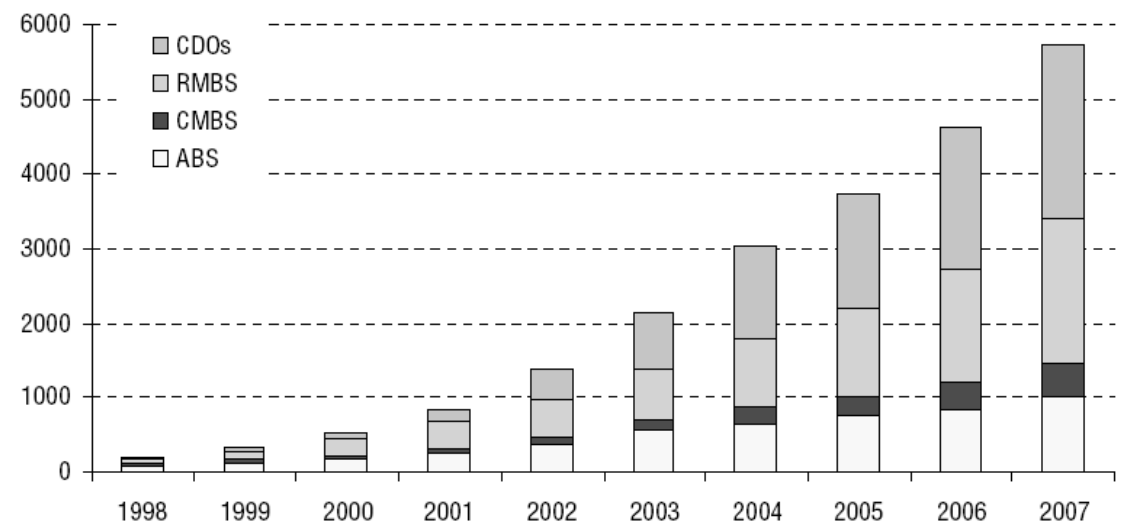

Source: Moody's: European Structured Finance Rating Transitions 1988-2006, 2007, 3, http://www. moodys.com/cust/content/content.ashx?source=StaticContent/Free\%20pages/Credit\%20Policy\%20R esearch/documents/current/2006400000428534.pdf.

6 Bernanke, B.: Global Imbalances: Recent Developments and Prospects, Bundesbank Lecture, Berlin, 11.09. 2007, http://www.federalreserve.gov/newsevents/speech/bernanke20070911a.htm.

7 Borio, C., op. cit., 3. 


\section{The Buildup of Vulnerability}

As it has been noted in the previous part, the enormous liquidity, which characterised the markets from 2001, flew primarily to the real estate sector. The subsequent rise in house prices enabled lenders to provide loans to more risky borrowers, since the repayment was guaranteed not by the income of the borrower, but rather by the rise in the value of the collateral. This meant that during this period, groups, which were previously denied credit, gained access to borrowing.

The risky borrowers can be divided into two categories: Alt-A and subprime. The risk in the Alt-A group comes from low documentation, which means that verification about income or whether there is another mortgage on the real estate is missing. In the subprime category borrowers have poor credit histories and usually little savings for down payment. ${ }^{8}$ In 2000 the share of these two categories of borrowers was only at $4 \%$, which rose to $25 \%$ by the beginning of 2007 (Figure 4). In 2006 almost $40 \%$ of new mortgages went to these groups.

Figure 4: Mortgage-based securities (MBS) outstanding (\$ billions)

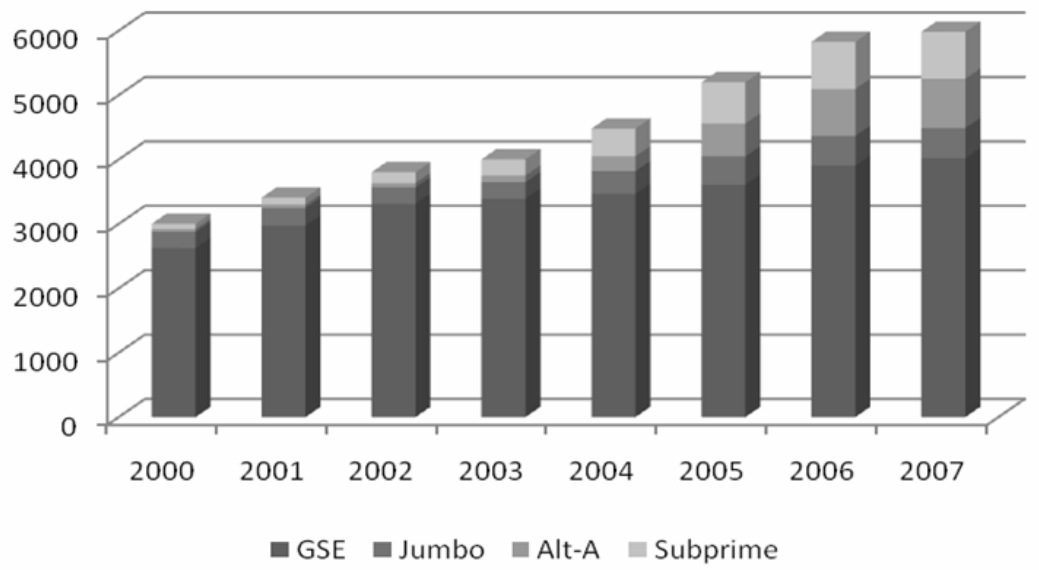

Notes: GSE: MBS holding government sponsored entities; Jumbo: prime borrowers with mortgages larger than allowed by GSE regulations. Alt-A, subprime: see text.

Source: Author's compilation using data from Gorton, G. B.: The Subprime Panic, NBER Working Paper No. 14398, 2008, 3.

8 For a detailed description of various risks of these borrowers see Mayer, C./Pence, K./Sherlund, S. M.: The Rise in Mortgage Defaults, in: Journal of Economic Perspectives, 23/1 (2009), 27-50. 
Creditors used two basic methods to mitigate their exposure to subprime risks the conditions of mortgages and securitisation. ${ }^{9}$ The most important feature of subprime loans was that they were hybrid loans, which means that they incorporated fixed and adjustable features. The loans had a low, fixed rate for the first two or three years, after which borrowers faced floating rates and had to pay the market rates, which could be 3-5 percentage points higher than their original interest rate. However, after the first period of the mortgage was over, there was a possibility for refinancing the mortgage depending on the rise in the price of the real estate. The practically meant an option for the mortgage provider to stop financing the borrower if they did not see the further increase in house prices ensured. ${ }^{10}$

Mortgage originators raised funds on the financial markets through selling securities created from their lending portfolio. Securitisation means that individual mortgages are pooled and then sliced up into different tranches based on the priority of claims on the collateral pools. The senior tranches offer relatively low interest rates but they are the first to be paid out of the cash flow of the portfolio, while the most junior tranches (or equity tranche) offer high returns but are paid only after all others. This method made it possible that many of the manufactured tranches are far safer than the average asset in the underlying pool. ${ }^{11}$ These new assets (collaterised debt obligations, $\mathrm{CDO}$ ) were then rated by credit-rating agencies, with the top tranches constructed to receive AAA rating, and/or ensured through credit default swaps (CDS), which are basically contracts against the default of a particular bond or tranche. By $2006,80 \%$ of the $\$ 1.2$ trillions subprime stock was securitised in this manner. ${ }^{12}$

9 In the following I will describe the originate-and-distribute (OAD) model only at a level that is necessary for understanding the next parts of the paper. For exhaustive description see for example Ashcraft, A.B./Schuermann, T.: Understanding the Securitization of Subprime Mortgage Credit. Staff Report No. 318. Federal Reserve Bank of New York, New York, 2008, http://papers.ssrn.com/sol3/ papers.cfm?abstract_id=1071189) and Gorton, G.B.: The Subprime Panic, NBER Working Paper No. $14398,2008$.

10 Gorton, G. B., op. cit., 4-6.

11 Coval, J./Jurek, J./Stafford, E.: The Economics of Structured Finance, in: Journal of Economic Perspectives, 23/1 (2009), 3-25, here 3.

12 Gorton, G. B., op. cit., 6. 


\section{Unfavourable Shock}

The working of the system was dependent upon two factors. The first condition was the steady increase of real estate prices, which ensured the refinancing of subprime loans. The second condition was market liquidity, which enabled market actors to buy and sell the new securitised products on the markets. Once these conditions came into question, the highly-leveraged financial institutions could expect non-linear losses. By 2007 both of these conditions evaporated.

House prices had been increasing for over more than a decade. This had a natural effect on the supply side and a real estate building boom followed the rise in prices. In 2005 there were more than 2 million housing starts, which is $50 \%$ more than the period before the bubble. ${ }^{13}$ The signs of oversupply showed up first on the rental market, where the share of vacancies grew from $7.5 \%$ in the mid-1990s to $9 \%$ by 2002 . The extraordinary financing conditions during the period afterwards prevented the collapse of house prices then, so the signs of oversupply showed up in the market for newly built houses only with a significant lag. By the fourth quarter of 2006, vacancy rate was over $50 \%$ above its prior peak. ${ }^{14}$ The oversupply eventually affected prices, and in the third quarter of 2007 prices declined by $4.5 \%$, which was the largest fall since 1988 . $^{15}$ Monetary restriction also contributed to this process, since in the second part of 2005 the FED started to raise interest rates (Figure 1), which made loans more expensive and thus decreased the demand for real estate.

The fall in real estate prices had severe implications for the all actors on the housing market. For borrowers the fall in prices implied that the subprime loans were not renewed, which caused a larger increase in debt service obligations after the fixed-rate period was over. For lenders the problem was that many home owners - especially those with very low initial downpayment - could end up with negative equity in their house, which means that they owned more than their house was worth. This implied that it made more sense financially to give back the keys of the house than continue with the payment of debt obligations. By 2007 these two factors together led to increased default rates of Alt-A and subprime loans. Compared to the year before, the number of foreclosures rose by

13 Baker, D.: The Housing Bubble and the Financial Crisis, in: Real-World Economics Review, 46/2008, 73-81, here 73 f., http://www.paecon.net/PAEReview/issue46/Baker46.pdf.

14 Ibid., 75.; Ellis, L.: The Housing Meltdown: Why did it Happen in the United States? BIS Working Paper No. 259, 2008, 2.

15 Gorton, G. B., op. cit., 20. 
$79 \%{ }^{16}$ This process not only increased the supply of real estate on the market but also raised the fears of investors, who reacted with stricter conditions for loans. The increase in the supply and the reduction of demand led to further decline in prices and a downward self-reinforcing spiral emerged on the market by the end of 2008, prices dropped by $30 \%$ in comparison to the top of the bubble in 2007 (Figure 1).

The first signs of problems in the financial market showed up in the ABX index, which was created in 2006 to give information on the risk of MBS with the following of the CDS prices. ${ }^{17}$ This index started to fall in February 2007 for the BBB rated papers containing subprime tranches. This led rating agencies to downgrade mortgage-based securities, which forced financial companies to write down enormous losses, ${ }^{18}$ thus contributing to a large decline in the demand for these securities.

\section{The Spread of the Crisis}

The first causality of the crises were banks' off-budget investment portfolios (special investment vehicles, SIV), which had to be taken back to the sponsor banks' balance sheet. These funds worked through using the possibilities for arbitrage by raising cheap, short-term loans and buying long-term, high-yield assets. With the large drop of $\mathrm{ABX}$ index creditors did not renew their short-term loans, which meant their end. ${ }^{19}$

16 Orlowski, L.T.: Stages of the 2007/2008 Global Financial Crisis: Is There a Wandering Asset-Price Bubble? Discussion Paper No. 43., Economics E-Journal, 9, http://mpra.ub.uni-muenchen.de/12696/.

17 Gorton, G. B., op. cit., $22 \mathrm{f}$.

18 The large losses were also due to the fair-value accounting rules, which were introduced in 2007. Its mark-to-market principle meant that companies had to account for their assets on basis of actual market prices. As the demand for much of their assets disappeared within weeks, they had to revalue their assets at very low prices. Furthermore in order to cover their losses, they had to sell marketable assets, which pushed down prices in other markets and led to further losses. See Whalen, C.R.: The Subprime Crisis Cause, Effect and Consequence, Policy Brief No. 04, Networks Financial Institute, 2008, 6-11, http://papers.ssrn.com/sol3/papers.cfm?abstract_id=1113888 and Roubini, N.: Ten Fundamental Issues in Reforming Financial Regulation and Supervision in a World of Financial Innovation and Globalization, in: Uzan, M. (ed.): Building an International Monetary and Financial System for the $21^{\text {st }}$ Century: Agenda for Reform. Ebook by the Reinventing Bretton Woods Committee, 2008, 197-210, here 206-208, http://media.rgemonitor.com/papers/0/RBWCAgendaforReformeBook.pdf.

19 As Gorton, G.B., op. cit., 25. claims, the fall of SIVs are more likely due to loss of confidence than fundamental problems. The exposure of these firms to subprime loans was rather small and their portfolio was well-diversified. 
In the next phase the panic spread to the interbank markets, where the TEDspread (difference between risky three-month interbank rates and risk-free government treasury) suddenly jumped in August 2007 in response to the fall of two hedge funds associated with Bear Stearns (Figure 5). The reason for the increase was that banks became worried that once they have to sell the collateral they receive for overnight loans, there will not be a market for it. ${ }^{20}$

Figure 5: TED-spread (basis point)

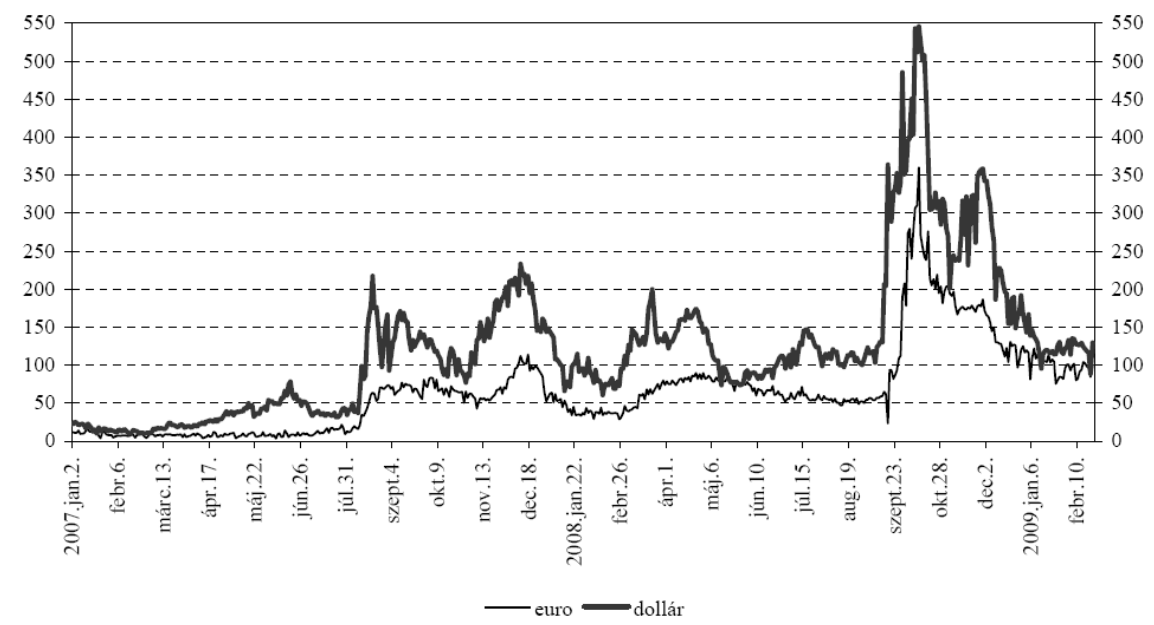

Source: Hungarian National Bank: Statistical Figures, http://www.mnb.hu/engine.aspx?page=mnbhu _statisztikak.

Due to the coordinated intervention of the FED, the ECB and the Bank of Japan, the TED-spread decreased. However, as shown by Figure 5, the decline proved to be only temporary. With the large losses revealed by various financial companies the spread increased again in December 2007 and April 2008. This mostly affected those companies, like Bear Stearns and Lehman Brothers, which most relied in their business on high leverage and short-term loans to finance long-

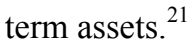

20 Ibid., 26.

21 The leverage of Lehman Brothers was close to 30 to 1 , which means that for every $\$ 100$ loan, they only had $\$ 3.3$ equity. This implies that a mere $3.3 \%$ drop in asset values was enough to make the company insolvent. Moreover, Lehman financed more than $50 \%$ of its assets through short-term loans, which carried the risk of renewal once there was a loss of confidence. See Zingales, L.: Testimony on "Causes and 
The bankruptcy of Lehman in September 2008 can be seen as the turning point of the crisis, which threatened with global systemic failure and triggered largescale government intervention on a previously unprecedented scale. ${ }^{22}$ The measures of the US authorities were soon followed by similar steps around the world placing an enormous burden of debt on taxpayers and future generations.

\section{The Main Actors in the Crisis}

The vast costs of bailouts quickly turned public attention to finding scapegoats. It did not take long before the greed of bankers was singled out as the major factor leading to the crisis. However, as Lawrence H. White points out, when we start looking for the causes of a plane crash we usually do not blame gravitation. ${ }^{23}$ In the following sections I show how the FED and the housing policy of the US government contributed to the exacerbation of the problems of asymmetric information that plagues the financial sector, and how their actions can ultimately be blamed for the crisis.

\section{Monetary Policy}

The extremely low interest rates, which were discussed in the previous section, and which meant negative real interest rates for almost three years, can be considered as a starting point for the financial crisis. However, this is not the only way through which the FED contributed to the accumulation of risks. As Claudio Borio and Haibin Zhu discuss, monetary policy can affect the risk perception of economic agents, and thus its signals about future interventions can play a critical role in investment decisions. ${ }^{24}$ The FED made several huge policy mistakes on this account.

The problems became first apparent during the management of the dot.com bubble. Given the belief in the new economy, which was expected to cause a steady

Effects of the Lehman Brothers' Bankruptcy", United States House of Representatives, 2008, 12, http:/oversight.house.gov/documents/20081006103245.pdf.

22 Calomiris, C. W.: The Subprime Turmoil: What's Old, What's New, and What's Next, paper presented at the $9^{\text {th }}$ Jacques Polak Annual Research Conference in Washington, DC, 2008, $55 \mathrm{f}$., http://www. imf.org/external/np/res/seminars/2008/arc/pdf/CWC.pdf.

23 White, L.H.: How Did We Get Into this Financial Mass? CATO Institute Briefing Papers No. 110., $2008,2$.

24 Borio, C./Zhu, H.: Capital Regulation, Risk-taking and Monetary Policy: A Missing Link in the Transmission Mechanism?, Working Paper no. 268., BIS, 2008. 
increase in productivity, from the mid-1990s a large bubble started to emerge on the US stock market (Figure 6). As a firm believer in the new economy, Alan Greenspan did not intervene in the bubble for two reasons. First, given the new economy and the possibility for a permanent productivity increase, he thought that there is a chance for a steadily low inflation environment. ${ }^{25}$ This implies that Greenspan was convinced that we only know whether a bubble was a bubble after it burst. Second, in 1997 they tried to raise interest rates, but they did not succeed in slowing down the stock price rise. ${ }^{26}$ After this attempt, no further effort was made to stop the blowing of the bubble, which is illustrated by Figure 6.

Figure 6: The S\&P 500 index 1990-2008 (monthly high)

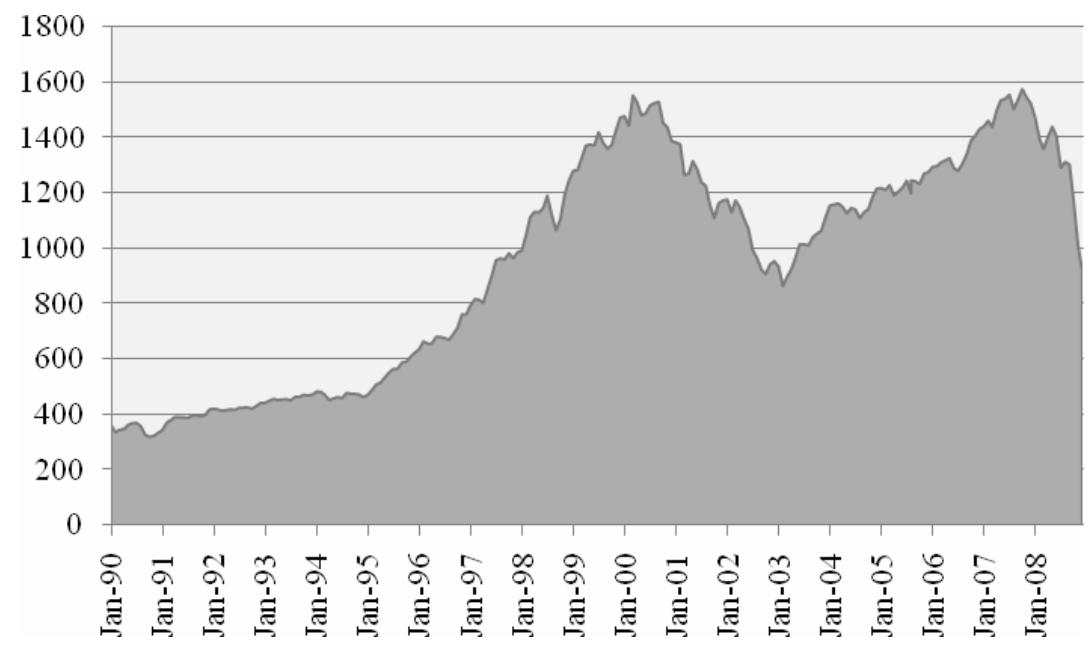

Source: Author's compilation using data from Economagic.com, http://sub1.economagic.com/emcgi/data.exe/sp/sp07.

Although the FED did not intervene into the growing of the bubble, William A. Fleckenstein makes the argument that it still regularly interfered with market

25 See Greenspan, A.: The Age of Turbulence: Adventures in a New World, New York, 2007, 167-173. In reality, as empirical evidence shows, global disinflation was not due to technology but rather to increased competition due to globalisation, see Rogoff, K.: Globalization and Global Disinflation, in: Economic Review - Federal Reserve Bank of Kansas City, 4Q/2003, 45-78.

26 Greenspan, A., op. cit., $178 \mathrm{f}$. 
activity through regularly cutting interest rates at the first signs of a downturn. This factor was in play when interest rates were cut three times in 1998 in response to the collapse of Long-Term Capital Management (LTCM). Although the economy itself did not give cause for worry (see Figure 1), the loss of confidence on the financial markets triggered a 0.25 point interest rate cut on 29 September. As market activity did not respond immediately, Greenspan called an extraordinary meeting for 15 October when another cut was decided. Fleckenstein emphasises that by this time markets rebounded and there was no emergency that required an extraordinary meeting. The result was an enormous jump on the markets and the spread of sentiment among investors that Greenspan would do anything to stop the market from a serious downturn. ${ }^{27}$

Letting bubbles grow unimpeded, while aggressively fighting market downturns means that during the 1990s FED monetary policy was working in a highly asymmetrical manner. It allowed markets work upward but did not allow them to work downward. This policy implied a serious distortion of incentives, greatly encouraged risk-taking and drove away fear from the markets.

However, monetary policy is only one side of the story. In the relaxing of lending conditions, the housing policy of the government played a critical role.

\section{Housing Policy in the US}

The enormous liquidity, which was created by the easy money policy of the FED, was not necessary to cause a bubble on the real estate market. For this to happen government intervention into the real estate market, aiming at increasing the rate of home ownership, was also necessary. Since the American public is traditionally sceptical with government spending, the objective had to be resolved in a manner, which does not have an impact on the government's balance sheet and does not increase the rate of redistribution. The government resolved this problem through government sponsored enterprises (GSEs) and the loosening of credit requirements.

Government involvement in the real estate market started after the Great Depres$\operatorname{sion}^{28}$ - during this period mortgage loans were only available for one or two

27 Fleckenstein, W.A./Sheehan, F.: Greenspan's Bubbles: The Age of Ignorance at the Federal Reserve, New York, 2008, 49-63.

28 In the following description on GSEs I rely on Liebowitz, S.J.: Anatomy of a Train Wreck: Causes of the Mortgage Meltdown. Independent Policy Report, Independent Institute, 2008, http://www. independent.org/pdf/policy_reports/2008-10-03-trainwreck.pdf, and Frame, S.W./White, L.J.: Fussing 
years, which made the purchase of real estate very difficult. In order to mitigate this problem in 1934 the government established the Federal Housing Administration (FHA), which guaranteed the mortgages of low-income borrowers under strict conditions, such as $20 \%$ downpayment on the house. Fannie Mae (Federal National Mortgage Association) was created in 1938 to purchase FHA loans and repackage them into securities. Later its purpose widened and now it purchases and repackages a large share of all private mortgages, which fulfil its acquisition criteria. The company was privatised through the New York Stock Exchange in 1968 by President Johnson, who was aiming at decreasing the budget deficit. Although it was privatised, Fannie Mae also preserved its government functions, which resulted in a peculiar arrangement. In spite of its private owners, from the beginning there was an implicit government guarantee on its debt, giving it a significant advantage for raising funds. On the other hand its dealings are restricted to private housing and the secondary market, thus it cannot directly originate mortgages. ${ }^{29}$ As Figure 4 shows the market share of GSEs is enormous, in 2000 they were responsible for $78 \%$ of mortgage-based securities (MBS). According to Peter J. Wallison and Charles W. Calomiris, this arrangement ultimately means the privatisation of profits and the socialisation of risks - the implicit government guarantee allowed these companies to take on excessive risks and the costs are born by taxpayers and not by shareholders. ${ }^{30}$ As the crisis unfolded and these companies had to put into federal conservatorship in September 2008, this view proved to be justified.

Government intervention into the real estate market increased in the 1970s, when concerns about discriminatory lending practices emerged. In order to fight this problem in 1977 the Community Reinvestment Act (CRA) was introduced, which obliged banks to conduct business across the entirety of the geographic areas in which they operated and not only in the wealthy neighbourhoods. ${ }^{31}$ Following this legislation banks had to comply not only with prudential standards

and Fuming over Fannie and Freddie: How Much Smoke, How Much Fire?, in: Journal of Economic Perspectives, 19/2, (2005), 159-184.

29 Freddie Mac (Federal Home Loan Bank Board) was founded in 1970 to securitise the Savings and Loans associations' mortgages and from 1989 it works in a similar manner as Fannie Mae.

30 Wallison, P.J./Calomiris, C. W.: The Last Trillion-Dollar Commitment: The Destruction of Fannie Mae and Freddie Mac, Financial Services Outlook, American Enterprise Institute for Public Policy Research, Washington DC, September 2008, 2, http:/www.aei.org/publications/pubID.28704,filter.all/ pub_detail.asp.

31 Liebowicz, S.J., op. cit., 6. 
but CRA standards as well - failure to do so could result in penalties. ${ }^{32}$ From 1991 banks also had to reveal race in their disclosure of loan applications. Once this data was available, it became the basis for a 1992 Federal Reserve Bank of Boston study, which showed that even after controlling for other relevant factors, loan applications from minorities were rejected at a much higher rate than white applications. While there were serious data problems with the study, ${ }^{33}$ the enormous media attention provoked a strong government reaction and gave incentive to the more effective application of CRA rules. This started the relaxing of lending standards.

The easing of lending standards started with the changing acquisition criteria in the GSEs as they were forced by the government to direct an increasing proportion of their dealings - by 2005 over $50 \%$ - to groups below the median income. ${ }^{34}$ These governmental requests had even more force after 2002-2003 as the GSEs got involved in the accounting scandals and their special privileges came into danger. ${ }^{35}$ During this process the previously strict acquisition criteria were gradually relaxed: credit history received less emphasis, the loan to income ratio was increased, the necessary downpayment was reduced from $20 \%$ to $3 \%$ and documentation requirements were also reduced. ${ }^{36}$

As the business of GSEs is concentrated on the secondary markets, the loosening of standards directly affected the mortgage originators. They were motivated to increase their risky lending from all directions: besides the enormous liquidity and the search for yields, there was a strong governmental pressure from the CRA, while at the same time risks were taken over by the GSEs. Once risky lending started, everyone had to follow since failure to do so could lead to a loss of market share.

At first the easing of lending standards fulfilled the expectations of the government and home ownership increased from 64 to $69 \%$ of the population. ${ }^{37}$ At the same time the easy availability of credit motivated not only the minorities to borrow but also the speculators, which will be discussed later.

32 If banks did not lend enough to disadvantaged groups heavy fines could be imposed on them. From 1995 banks with low CRA scores could be also denied mergers with other banks or the opening of new branches - according to White, L.H., op. cit., 5, this was the real breakthrough for taking CRA seriously.

33 Liebowicz, S.J., op. cit., 6.

34 White, L.H., op. cit., 5.

35 Wallison, P.J./Calomiris, C.W., op. cit., $4 \mathrm{f}$.

36 Liebowicz, S.J., op. cit., 7-10.

37 Ibid., 16. 
Overall the housing policy of the government introduced serious distortions on the real estate market and strongly contributed to greater risk-taking in lending, which could be observed on Figure 4 in the growing share of Alt-A and subprime loans. The spread of these risky loans greatly exacerbated the inherent asymmetric information problems on the financial markets, which is the subject of the next section.

\section{Financial Markets}

In spite of the revolution in financial innovation that took place in the past decades, Borio emphasises that asymmetric information is an unchanged attribute of financial relationships. ${ }^{38}$ This means that as partners in a financial transaction do not have equal access to information, the problems of adverse selection, moral hazard and principal-agent problems are to be expected. In the originate-anddistribute (OAD) model of the US real estate markets, these problems can be observed at every level of the financing process. Ashcraft and Scheurman as well as Baker list a number of such frictions. ${ }^{39}$ From the perspective of this paper, the following frictions deserve special emphasis:

(1) Mortgagor and originator: since originators earn their money from issuing the mortgage and not from holding it, they have incentives to increase the quantity of mortgages. Subprime borrowers typically lack financial sophistication, so they can be persuaded to take "welfare-reducing" loans, which they are unable to repay later (predatory lending).

(2) Mortgagor and appraiser: as appraisers were hired by mortgage issuers and recognised that their clients wanted appraisals justifying the mortgage, there emerged a strong incentive to give high valuations. Initially this was beneficial to all - the applicant received the loan, the originator the fee, and the appraiser the fee as well as further business from the bank. As house prices collapsed and borrowers defaulted, the losses had to be borne by the investors.

(3) Originator and arranger: the originator of the loan has more information on the quality of borrower than the institution securitizing the loan. However, since the latter sells the securities and receives the fee from securitisation, it is not interested in conducting due diligence during the process but rather has an incentive to increase the quantity securitised.

38 Borio, C., op. cit., 9.

39 Ashcraft, A. B./Scheurman, T., op. cit. and Baker, D., op. cit. 
(4) Arranger and investors: the arranger has more information on the securities than the investors so it can keep the good papers and sell the bad ones, which means that the process was associated with a purposeful adverse selection of risk. $^{40}$

(5) Credit-rating agencies and investors: credit-rating agencies are paid not by the investors but by the sellers, which creates a conflict of interest since sellers have an incentive to conduct business with the credit rating agency that gives them the highest rating. Calomiris provides a detailed overview about how a race to the bottom was started on the credit rating market. ${ }^{41}$ The relative novelty of subprime securities and the lack of reliable time series on their default rates facilitated the competitive easing of rating standards. ${ }^{42}$ This brought them lucrative business opportunities and by $200642 \%$ of their revenue came from rating structured products, while only $32 \%$ came from their traditional business of rating corporate bonds. ${ }^{43}$ Besides these problems, Liebowicz also points out that rating agencies, which are heavily protected by government regulation from competition, did not want to risk their privileged status by undermining the government's policies on the housing market. ${ }^{44}$

Considering the wrong incentives in all stages of housing finance it becomes clear why it was so dangerous to relax lending standards. In the long chain of the OAD model, the problem of asymmetric information is present all over, and its dangers can be avoided only if there are quality borrowers at the beginning of the financing chain. Governmental interference undermined this critical condition.

The information problems that are endemic in the OAD model provide an explanation for the supply of these papers but do not explain their demand. The key factor here is the difference in yields of similarly rated mortgage backed securities and corporate bonds - an AAA rated corporate paper gives considerably less yield than an AAA rated MBS. ${ }^{45}$ The apparently low risk and relatively high yield made these papers extremely attractive - especially for those institutional investors, such as pension funds, whose possibilities for risk-taking is heavily

40 Calomiris, C.W., op. cit., 26.

41 Ibid., $31 \mathrm{f}$.

42 Coval, J./Jakub, J./Stafford, E., op. cit. provide an excellent discussion about how difficult it is to rate structured products and how sensitive the models are to parameter estimates on default and recovery rates as well as systemic events.

43 Ibid., $4 \mathrm{f}$.

44 Liebowicz, S.J., op. cit., 12.

45 Ashcraft, A. B./Scheurman, T., op. cit., 11, $62 \mathrm{f}$. 
regulated by the state. Besides rating arbitrage, Markus K. Brunnermeier also emphasises the importance of regulatory arbitrage: by holding AAA rated securities financial companies can keep their capital requirements low. ${ }^{46}$ The demand for these papers fuelled their supply and all actors had incentives to increase their exposure to the risks of subprime lending.

\section{Households}

The final actors to be discussed are the households. Similarly to investors, households were also highly motivated to increase their indebtedness in an environment of enormous liquidity. Besides the negative real interest rates, two institutional factors played a key role in this.

(1) Housing policy in the US encourages home ownership not only through the creation of GSEs, but also through the tax deductibility of mortgage payments. The unintended consequence of this rule is that home owners have no incentive to pay off their mortgage fast but instead they can gain from increasing their mortgage and finance their consumption from such loans - which basically means treating their houses as an $\mathrm{ATM}{ }^{47}$ This strategy was also supported by Greenspan, since after the dot.com bubble it created an opportunity to increase consumption. $^{48}$

(2) If the households cannot pay their mortgage, the bankruptcy regulation is rather lenient - the mortgager just simply drops the keys and can walk away since given the high costs of litigation, banks usually take the losses. ${ }^{49}$ This implies that the home owner can win on the increase of the house prices but can walk away from the losses.

Besides the factors that were cited earlier (cheap credit and lax lending standards) the two factors above also played a critical role in the fact that real estate speculation, when the real estate is bought not for living but for selling, became extremely widespread. Since it was easy to get loans and house prices increased, investors could acquire real estate and expect profit with $0 \%$ investment and little risk. Once prices began to fall, they did not pay their loans any further, but

46 Brunnermeier, M.K.: Deciphering the Liquidity and Credit Crunch 2007-2008, in: Journal of Economic Perspectives, 23/1 (2009), 77-100, here 81.

47 Ellis, L., op. cit., $17 \mathrm{f}$.

48 As shown by his testimony before Congress on 21 November 2002, Greenspan was an enthusiastic supporter of this idea. His speech is cited by Fleckenstein, W.A., op. cit., $139 \mathrm{f}$.

49 Ellis, L., op. cit., $19 \mathrm{f}$. 
gave the keys back to the banks instead. According to Liebowicz, in 2005 28, in $200622 \%$ of house buyers were speculators. ${ }^{50} \mathrm{He}$ argues that this group probably played a critical role in the eruption of crisis, which can be supported by two kinds of empirical observation. First, the ratio of non-performing loans increased primarily in areas, like Florida, Las Vegas and California, where speculation was rampant. Second, it was not only subprime, but also prime borrowers who defaulted, which hints that in many cases the problem was negative equity in the house rather than the inability to pay the loans. ${ }^{51}$

Figure 7: Household debt service ratio: payments as \% of disposable personal income

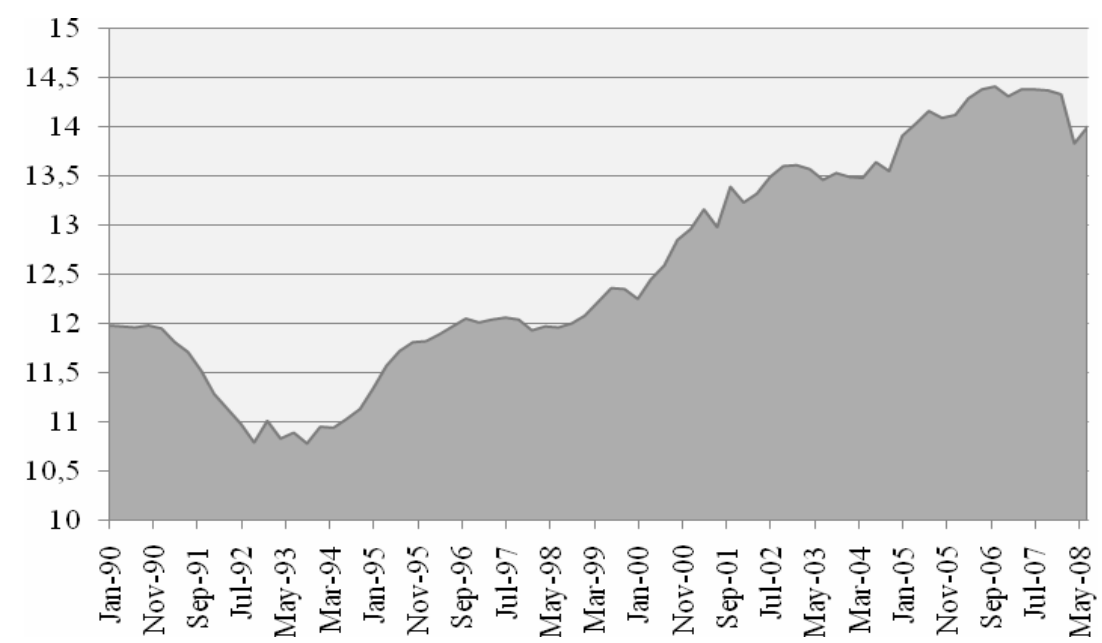

Source: Author's compilation using data from Economagic.com, http://sub1.economagic.com/emcgi/data.exe/frbfor/DSR.

Overall, it can be seen that government intervention in the markets distorted incentives not only for the actors in the financial sector but also for households, which were motivated to borrow and increase their consumption both by low credit costs and favorable regulations. The result was a considerable increase in

50 Liebowicz, S.J., op. cit., 24.

51 The findings of Mayer, C./Pence, K./Sherlund, S.M. op. cit., 45-49 also give support to Liebowicz' view. 
household debt service ratio as shown by Figure 7. As the crisis erupted and credit became more expensive while unemployment increased, servicing this debt burden necessitated a sharp cut back in consumption, which in turn exacerbated the downturn in the real economy.

\section{Illusions and Reality}

The previous part of this contribution showed how governmental policy distorted the incentives of market actors and how this led to the accumulation of risk in the system. As we can take it self-evident that the objective of the government was not the ruining of the economy, it is important to ask what kind of beliefs and expectations guided its policy.

A characteristic belief in the 1990s was the enthusiasm about technological progress. Progress in information technology and the revolution in financial engineering made it seem that a new era came for the world economy. In the brave new world one could count on a steadily higher rate of productivity than before, full employment as well as the disappearance of business cycles. ${ }^{52}$ The new era thinking is not a new phenomenon in economic history. According to Shiller, in the $20^{\text {th }}$ century it was present in the 1920 s, 1950 s and the 1990s. It is somewhat ironic that these eras generally preceded the greatest economic and social disruptions. $^{53}$

In the 1990s, the IT revolution opened new opportunities for financial engineering and large advances were made in the management of financial risks. Advances in structured finance, which made it possible to originate papers from a given portfolio that are safer than the average of the underlying portfolio, were already discussed. The other important innovation concerns the development of complex models for risk-analysis. The most important among these are the Value-at-Risk (VaR) models, which were developed at J.P. Morgan. ${ }^{54}$ These models could estimate the greatest possible loss of a portfolio in a given period at a given confidence level, generally $99 \%$. Through this model investors could

52 See for example Weber, S.: The End of the Business Cycle?, in: Foreign Affairs, 76/4 (1997), 65-82. He expected that wise governmental policy, advances in information technology and globalisation will bring about the disappearance of business cycles. Similar expectations are voiced by Greenspan, A., op. cit., 164-179.

53 Shiller, R.J., op. cit., 96-117. It is the same in the case of financial markets. According to Borio, C., op. cit., 9., the risk-perception of actors is the lowest at the top of the bubble.

54 The following discussion is based primarily on Jorion, P.: Value at Risk: The New Benchmark for Controlling Market Risk, New York, 1997. 
gain daily information not only about the risk of a given asset, but also about the risk of their total portfolio. VaR thus made it possible to take risks according to their preferences as well as evaluate the performance of their traders not only based on the profits they made but also on the accompanying risks. These advances soon found their way to the regulatory authorities, who also struggled to assess the risks of new instruments. Once they recognised that their models are inferior to the newly built business models, the Basel Committee allowed the largest banks to use their own models to determine their capital requirements.

At first, technical innovations seemed to work perfectly. The quantitative funds made enormous amount of money with apparently no risk through using the arbitrage opportunities on the markets. If there were warning signs, such as the fall of LTCM in $1998^{55}$, these were considered as unique events, and investors placed even more emphasis on understanding risks through $\mathrm{VaR}^{56}$. The subprime crisis however showed the extreme shortcomings of believing only in the models. As it was mentioned in the previous part the basic problem was that in the case of new products there was not enough data to conduct reliable analysis of risks with these models. ${ }^{57}$ Another problem was that these models predicted the losses with $99 \%$ confidence, and investors were liable to forget about the remaining $1 \%$, the tail risks, when losses could be substantially greater than predicted.

However, besides data quality and tail risks even more significant problems became apparent with the models. One of these problems can be seen as the manifestation of Goodhart's Law, which says that once decision-making relies on a numerical indicator, actors focus on complying with the indicator rather than with the underlying objective. In the case of VaR, this meant that traders started concentrating on assets, like CDS, which bring steady profits $99 \%$ of the time but cause enormous losses if the $1 \%$ materialises. ${ }^{58}$ Keeping VaR low was

55 In his account of the LTCM crisis, Nicholas Dunbar makes the argument that the automatic triggers of VaR models are to blame for the depth of the crisis - in order to cover the losses from the Russian market traders had to sell profitable assets elsewhere, which caused a collapse of prices in other markets. See Dunbar, N.: Inventing Money: The Story of Long-Term Capital Management and the Legends Behind It, Chichester, 2000.

56 Nocera, J.: Risk Mismanagement, in: The New York Times Magazine, 04.01. 2009.

57 In their analysis about why the models did not work Kristopher Gerardi et al. show that the underestimation of the possibility of a severe decline in house prices was the major failure of the risk assessments. See Gerardi, K. et al.: Making Sense of the Subprime Crisis. Public Policy Discussion Paper No. 1, Boston: Federal Reserve Bank of Boston, 2009, http://www.bos.frb.org/economic/ppdp/2009/ ppdp0901.pdf.

58 Nocera, J., op. cit. 
also a way for companies to keep their capital requirement low. ${ }^{59}$ Besides the possibility for manipulation, the second important problem was that VaR does not protect against systemic risks as its assumptions are by definition based on normal market conditions. In times of crisis, the procyclicality of VaR comes to the fore: when asset prices are high there are low capital requirements, and when asset prices fall, capital requirement rise - which starts a downward spiral of selling assets and fall in their prices. ${ }^{60}$

The inventors of VaR however never claimed that the models protect from all kinds of risks. The last chapter of Jorion's VaR textbook gives a long description of the limits of risk-modeling. Similarly, Robert Merton in his Nobel lecture warned that financial innovations and models will never be able to perfectly capture the full complexity of reality. ${ }^{61}$ In spite of these warnings, VaR became one of the leading scapegoats for the subprime crisis as it was seen to have contributed to a false feeling of security among investors and the taking of excessive risk. $^{62}$

Beyond the apparent belief in technology however, it is not difficult to find selfinterested actors. For investors the neglect of the limits of the models allowed them to take on excessive risks and assure high yields - especially when everybody else was doing the same. ${ }^{63}$ Those who followed a more prudent strategy could end up with comparatively lower profits that could endanger not only their compensation but even their jobs.

While the investors had obvious motivation for neglecting the risks, it is a more interesting to ask why the monetary authorities and the government did the same. On the surface we see here a blind faith in the models - as the dot.com bubble was growing it was Greenspan, who characteristically pointed out that it is very difficult to tell whether there is a bubble considering the extensive data and so-

59 Danielsson, J.: Blame the Models, in: Journal of Financial Stability, 4/4 (2008), 321-328, here 327.

60 Criticism of the procyclicality in Basel II regulation is voiced among others by Eatwell, J.: Risk Management and Systemic Risk, in: Estrin, S./Kolodko, G.W./Uvalic, M. (eds.): Transition and Beyond: Essays in Honour of Mario Nuti, New York, 2007, 247-263 and Roubini, N., op. cit.

61 Merton, R.C.: Applications of Option-Pricing Theory: Twenty-Five Years Later. Nobel Lecture, Stockholm, 1997, http://nobelprize.org/nobel_prizes/economics/laureates/1997/merton-lecture.pdf.

62 Danielsson, J., op. cit.; Nocera, J., op. cit.

63 Brunnermeier, M.K., op. cit., 82 cites the former chief of Citigroup, Chuck Pence, who referred to Keynes' analogy between bubbles and musical chairs in July 2007: "When the music stops, in terms of liquidity, things will be complicated. But as long as the music is playing, you've got to get up and dance. We're still dancing." 
phisticated models of thousands of analysts. ${ }^{64}$ In his autobiography he also goes at length into the difficulties of state regulation and believes primarily in the selfregulation of the markets. He also believed that the new complex products smooth the volatility of the market and contribute to greater efficiency - and the rare failures are unable to rock the entire system. ${ }^{65}$ These beliefs were widely shared among policy-makers and the academia as no effort was made to regulate the emerging off-budget investment funds of major banks or the new financial products. With such beliefs it is not surprising that neither the FED nor other regulatory agencies used their regulatory power to oppose the relaxing of lending standards or fight the building up of enormous leverage in the financial system.

As it was already mentioned the New Era thinking is a recurrent phenomenon in history, so beyond the false beliefs in technological progress there might be no need for further explanation. At the same time we also have to notice that this belief served not only the interests of investors but was very convenient for policy-makers as well. The fast-growing economy and the enormous consumption greatly increased the popularity of the leaders. The minority groups that became home owners through the government's affordable housing program represented non-negligible number of voters for any government. It is thus less then surprising that behind the overly optimistic decisions we can find rational political calculation. George Soros for example attributes the long period of negative real interest rates to the elections in 2004. ${ }^{66}$ Calomiris argues that the FED's inaction about lending standards to its desire to avoid serious political conflict over the housing policy of the government. ${ }^{67}$ White as well as Wallison and Calomiris emphasise the enormous campaign contribution made by GSEs to Congress representatives, who in turn supported them in keeping their privileged position on the real estate market. ${ }^{68}$

Once we consider the political economy factors in the subprime crisis it loses its unique character. We see an old familiar theme - the myth of plenty that has characterised all socialist efforts. Friedrich A. von Hayek expressed its dangers as the following: "the reader may take it that whoever talks about the potential

64 Fleckenstein, W.A., op. cit., $66 \mathrm{f}$. cites a speech by Greenspan in Chicago to support this point.

65 Greenspan, A., op. cit., 372-376.

66 Soros, G.: The New Paradigm for Financial Markets: The Credit Crisis of 2008 and What it Means, New York, 2008, 119.

67 Calomiris, C. W.: The Regulatory Record of the Greenspan FED, in: American Economic Review, 96/2 (2006), 170-173, here 171.

68 White, L.H., op. cit.; Wallison, P.J./Calomiris, C.W., op. cit. 
plenty is either dishonest or does not know what he is talking about." ${ }^{, 69}$ Ludwig von Mises called this the Santa Claus fable of the welfare school, which does not take into account the scarcity of capital and is committed to the policy of low interest rates, credit expansion and deficit spending - "it seems easy to find a remedy for all ills, to give to everybody 'according to his needs' and to make everyone perfectly happy"70. They showed how such a policy course leads to inflation, destroys incentives in the economy and serves only the interests of a particular group that aims at gaining power.

To the Central European observer the "myth of plenty" is also familiar from the post-socialist period. As transformation was accompanied by unrealistic expectations of a fast convergence with the standards of living in Western Europe ${ }^{71}$, policy-makers were hard pressed to implement policies, which fulfil those expectations as fast as possible. In Hungary this took the form of populist overspending, enormous budget deficit and increasing indebtedness, ${ }^{72}$ while in other countries of the region a new type of macroeconomic populism has emerged, which focuses not on the expenditure side of the government budget but rather on relaxing the revenue side and financial regulations. ${ }^{73}$ After decades-long repression of consumption lax regulations on foreign currency denominated borrowing and the ensuing indebtedness provided a sense of improved living standards in these countries, but as the global crisis evolved, they were pushed to the edge of financial collapse.

Overall the seemingly costless solutions to fulfil the expectations of voters turned out to be very expensive to tax payers and future generations both in the United States and in Central and Eastern Europe. In the US increasing home ownership through financing subprime loans directly from the budget would have been considerably cheaper, less than $\$ 2$ trillion, while the costs of the crisis are likely to be several times of this amount. In Central Europe, those countries, which were most irresponsible with foreign indebtedness (Hungary and the Baltics), are seeing a sharp contraction in their growth rates and a likely reversal in the convergence process - thus their hasty policies to quickly make up for the

69 Hayek, F. A.: The Road to Serfdom, London, 1944/1991.

70 Mises, L.: Socialism, $3^{\text {rd }}$ ed., New Haven, CT, 1962, 848-851.

71 See Kornai, J.: The Great Transformation of Central Eastern Europe: Success and Disappointment, in: Economics of Transition, 14/2 (2006), 207-244.

72 See Györffy, D.: Governance in a Low-Trust Environment: The Difficulties of Fiscal Adjustment in Hungary, in: Europe-Asia Studies, 58/2 (2006), 239-259.

73 Csaba, L.: Crisis in Economics?, Budapest, 2009. 
lost decades of consumption ultimately prolong the fulfilment of their expectations.

\section{Conclusions}

At the time of Keynesian resurgence, this contribution examined the role of the state in the evolution of the subprime crisis. Looking at the incentives of the various actors in the crisis, it was shown that the monetary policy of the FED and the housing policy of the US government greatly distorted market incentives and contributed to the excessive risk-taking of financial market actors and households. Refusal to impose stricter regulations on the financial sector in the name of free market ideology exacerbated the situation and reflected the philosophical incoherence of American economic policy - as the experiences of socialism show, once there is bureaucratic interference into the workings of the market, further interference becomes necessary in order to manage the unintended consequences. $^{74}$

While on the surface technological progress can account for these policies, it is not difficult to see the political interests and the vote-maximizing efforts behind them. Even if we give the benefit of doubt and accept that government actors were sincere in their beliefs in technological progress and the opportunities it brings, their contribution to the crisis should still make us careful about solutions, which favour greater state involvement in the economy and aim at restraining markets. There is no guarantee that policy-makers will act any wiser in managing the crisis than in bringing it about - especially as we see that the policies designed to resolve the crisis are no different from the ones that caused it. As the world starts to move towards greater state intervention decades of experiences with socialism in Central and Eastern Europe should not be forgotten.

74 Mises, L., op. cit., 533; Kornai, J.: The Socialist System: The Political Economy of Communism, Oxford, 1992, 565-567. 